\title{
Bond Strength Between Fiber Posts and Composite Resin Core - Influence of Temperature on Silane Coupling Agents
}

\author{
Veridiana Resende NOVAIS ${ }^{1}$ \\ Paulo Cézar SIMAMOTO JÚNIOR ${ }^{2}$ \\ Regina Maria Puppin RONTANI ${ }^{3}$ \\ Lourenço CORRER-SOBRINHO ${ }^{3}$ \\ Carlos José SOARES ${ }^{1}$
}

\author{
${ }^{1}$ Department of Operative Dentistry and Dental Materials, Dental School, \\ UFU - Federal University of Uberlândia, Uberlândia, MG, Brazil \\ ${ }^{2}$ Department of Fixed Prosthodontics, Occlusion and Dental Materials, Dental School, \\ UFU - Federal University of Uberlândia, Uberlândia, MG, Brazil \\ ${ }^{3}$ Department of Dental Materials, Piracicaba Dental School, UNICAMP - University of Campinas, Piracicaba, SP, Brazil
}

\begin{abstract}
This study evaluated the effect of air drying temperature and different silane coupling agents on the bond strength between glass fiber posts and composite resin core. The post surface was cleaned with alcohol and treated with different silane coupling agents, being three prehydrolyzed silanes [Silano (Angelus), Prosil (FGM), RelyX Ceramic Primer (3M ESPE)] and one two-component silane [Silane Coupling Agent (Dentsply)]. Two post-silanization air drying temperatures, $23^{\circ} \mathrm{C}$ and $60^{\circ} \mathrm{C}$, were applied. A cylindrical plastic matrix was placed around the silanized post and filled with composite resin. Each bonded post provided 7 slices for push-out testing. Each slice was loaded to failure under compression at a cross-head speed of $0.5 \mathrm{~mm} / \mathrm{min}$. Data were analyzed by two-way ANOVA and Scott-Knott tests $(\alpha=0.05)$. Dunnett's test was used to compare the mean of the control group with that of each experimental group. Scanning electron microscopy (SEM) was used to evaluate the interface of the fractured slices. For the $23^{\circ} \mathrm{C}$ air drying temperature, the use of RelyX Ceramic Primer resulted in significantly lower bond strength than the other silane coupling agents, while the bond strength with Silane Coupling Agent was the highest of all groups. Only with Silane Coupling Agent, the bond strength for the $23^{\circ} \mathrm{C}$ air drying temperature was significantly higher than that for $60^{\circ} \mathrm{C}$ air drying. In conclusion, the use of warm air drying after silane application produced no increase in the bond strength between the fiber-reinforced composite post and the composite core. The twocomponent silane produced higher bond strength than all prehydrolyzed silanes when it was used with air drying at room temperature.
\end{abstract}

Key Words: composite resin, fiber-reinforced post, bond strength, silane.

\section{INTRODUCTION}

Endodontically treated teeth with excessive wear result in a lack of coronal tooth structure and frequently need post to retain the coronal restorative portion $(1,2)$. The presence of significant coronal tooth structure loss requires abutment build-up around a fiber-reinforced composite (FRC) post (1). Posts form a bonded unit between root and coronal dentin, adhesive systems, resin cements, and composite build-up (3). The most common failure of endodontic-treated teeth restored with FRC post during fracture testing is failure involving core portion (4). The retention and stability of the posts systems and core build-up is an important factor for successful restoration (5). Retention of the core portion around the post is promoted by both micromechanical and chemical interaction between post and resin composites (1).

Silane coupling agents have been widely used in dentistry since the introduction of glass fiber-reinforced resin-based materials. A chemical bond may be achieved between the core resin matrix and the exposed glass fibers of the post (6). The results of some studies advocate for silane capability of increasing surface wettability resulting in chemical bridges formation with OH-covered substrates (e.g., glass or quartz fibers) (7). 
Additionally, it has been reported that silane coupling agent significantly improved the bond strength between FRC posts and composite core build-up materials (6).

However, silane coupling is considered a technique-sensitive step. The bond strength of composite to FRC posts can be affected by different composition of silane coupling agents and the air drying temperature (8). Solvent evaporation plays an important role; a small amount of solvent may be beneficial in promoting silane wetting, but an incomplete removal may compromise coupling (9). A stream of warm air may be used to assist evaporation of solvents and reaction products on the silane-treated surface, which results in a dried surface (10). Significant improvement in shear bond strength after heat treatment of the silanized porcelain can be attributed to the elimination of water, alcohol, or acetic acid from the silane-treated surface (11). Ethanol/waterbased silanes have a more stable behavior, probably due to the mixing ratio of the two solvent components. At temperatures of $21^{\circ} \mathrm{C}$ and $38^{\circ} \mathrm{C}$, no significant differences were present in the water evaporation rate (8). It is likely that higher values of temperature may facilitate water removal and could increase bond strength (8). Scarce information exists about the influence of post-silanization air drying on bond strength between fiber post and core resin regarding different silanes couple agents.

The aim of this study was to evaluate the push-out bond strength between the glass fiber post and composite resin core influenced by the temperature on different silane coupling agents. The hypothesis generated is that drying with a stream of warm air the post surface after silanization increases the push-out bond strength of composite resin core to glass fiber post compared with that produced by room temperature air drying.

\section{MATERIAL AND METHODS}

Ninety glass fiber posts (Exacto; Angelus, Londrina, PR, Brazil; size 2, $17.0 \mathrm{~mm}$ long x 1.50 mm diameter) composed of unidirectional glass fibers ( $87 \%$ volume) embedded in an epoxy resin matrix were used for testing. All posts were cleaned with alcohol, dried with an air stream and randomly divided into 9 groups $(\mathrm{n}=10)$. The groups included 1 control group and 8 experimental groups, according to the two study factors: 4 silane coupling agent types (Table 1) and 2 temperatures of air drying of post surface after silanization $\left(23^{\circ} \mathrm{C}\right.$, representing room temperature and $60^{\circ} \mathrm{C}$, representing a warm air stream). Group 1 (control) had no surface treatment. In groups 2, 4, 6 and 8, Silano (Angelus), Prosil (FGM, Joinville, SC, Brazil), RelyX Ceramic Primer (3M ESPE, St. Paul, MN, USA) and Silane Coupling Agent (Dentsply, Petrópolis, RJ, Brazil) were used, respectively, followed by drying with an air stream at $23^{\circ} \mathrm{C}$ (room temperature). In groups 3 , 5,7 and 9, the same agents were used, respectively, followed by drying with an air stream at a temperature of $60^{\circ} \mathrm{C}$. The silane agents were applied according to the manufacturers' recommendations and their composition and application mode are described in Table 1.

Air dying at room temperature was performed with gently air of air syringe at $23 \pm 1^{\circ} \mathrm{C}$, controlled by a thermometer fixed close to the workbench. Aminiaturized hairdryer (Model 1808A, 50-60 Hz, 1200W; Sokany, Zhejiang, China) was used to perform warm air drying at $60^{\circ} \mathrm{C}$. To standardize and control the temperature, a Type $\mathrm{T}$ (copper-constantan) thermocouple, which is widely used for low-temperature measurements in laboratory, was used. This Type T thermocouple wire was connected to the data acquisition device (ADS0500IP; Lynx Tecnologia Eletrônica Ltda., São Paulo, SP, Brazil). At the moment that the hairdryer was turned on, the temperature was transferred to a computer that used specific acquisition, signal transformation, and data analysis software (AqDados 7.02 and AqAnalisys; Lynx Tecnologia Eletrônica Ltda.).

After silanizing post surface, composite resin build-up was performed using a special device to centralize the posts (12). Each post was positioned upright in the center of the device (Fig. 1A). Then, a cylindrical plastic matrix $(10 \mathrm{~mm}$ long and $5 \mathrm{~mm}$ diameter) was placed around the post and adjusted in such a way that the post would be exactly in the middle. The matrix was filled incrementally with a hybrid composite resin (Filtek Z250; 3M ESPE). Photoactivation of each 2-mm-thick increment was performed at the top of the tube using a LED unit at $1,200 \mathrm{~mW} / \mathrm{cm}^{2}$ (Radii-cal LED; SDI, São Paulo, SP, Brazil). The matrix allowed obtaining composite build-ups with standardized shapes and equal distribution of the core material around the posts. The specimens were removed from the matrix and stored in distilled water at $37^{\circ} \mathrm{C}$ for $24 \mathrm{~h}$.

\section{Push-Out Testing}

Each specimen was cut perpendicular to the long axis into 7 slices of $1.00 \pm 0.05 \mathrm{~mm}$ (Fig. 1B) with a slow-speed diamond saw under water cooling 
(IsoMet 1000; Buehler Ltd, Lake Bluff, IL, USA). The thickness of each slice was measured using a digital caliper to confirm accuracy, and the value was recorded. Seven slices were obtained from each post-and-core specimen, thus providing a total of 70 slices per group. To calculate the exact bonding surface, the tapered design of the posts with regard to the respective part of the post was considered. Each specimen was measured with a measuring microscope (TM-505- Toolmaker's Microscopes; Mitutoyo, Suzano, SP, Brazil). This step analyzed the integrity of the slices and eliminated specimens with failures like bubbles or cracks. The bonding surface was calculated considering that $\pi$ is the constant 3.14; R1 is the larger radius; $\mathrm{R} 2$, the lower
A

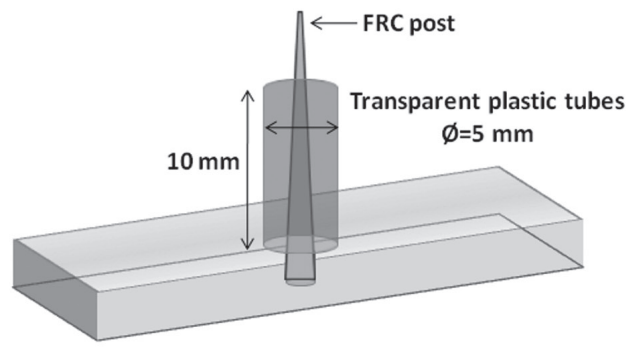

B

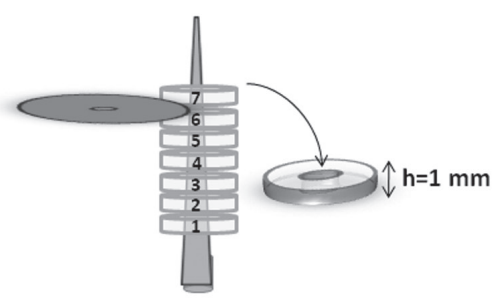

Figure 1. $A=$ Schematic view of the specimen preparation procedure; $B=$ Sectioning of post-and-core specimens for push-out test.

Table 1. Features of materials used in the study.

\begin{tabular}{|c|c|c|c|c|}
\hline Material/ Manufacturer & Composition & Solvent & Batch & Application mode \\
\hline $\begin{array}{l}\text { Silano; Angelus, Petrópolis, } \\
\text { RJ, Brazil }\end{array}$ & $\begin{array}{c}\text { X-R-Si(OR)3n } \\
\text { X-organofunctional group; } \\
\text { R-methylene group; } \\
\text { OR-hydrolizable group; } \\
\text { Si-Silicon }\end{array}$ & Ethanol & 10975.T & $\begin{array}{l}\text { Clean with alcohol and dry } \\
\text { with air. Apply silane with a } \\
\text { brush, wait } 1 \text { min and gently } \\
\text { dry with air }\end{array}$ \\
\hline $\begin{array}{l}\text { Prosil; FGM, Joinville, SC, } \\
\text { Brazil }\end{array}$ & $\begin{array}{l}\text { 3-methacryloxypropyltrimethoxysilane } \\
\text { (MPS) }\end{array}$ & $\begin{array}{l}\text { Ethanol, } \\
\text { water }\end{array}$ & $\begin{array}{l}2010 . \\
\text { OCT }\end{array}$ & $\begin{array}{l}\text { Clean with alcohol and dry } \\
\text { with air. Apply silane with a } \\
\text { brush, wait } 1 \text { min, and gently } \\
\text { dry with air }\end{array}$ \\
\hline $\begin{array}{l}\text { RelyX Ceramic Primer; } 3 \mathrm{M} \\
\text { ESPE, St. Paul, MN, USA }\end{array}$ & $\begin{array}{l}\text { 3-methacryloxypropyltrimethoxysilane } \\
\text { (MPS) }\end{array}$ & $\begin{array}{l}\text { Ethyl } \\
\text { alcohol, } \\
\text { water }\end{array}$ & $8 Y \mathrm{P}$ & $\begin{array}{l}\text { Clean post with alcohol, air } \\
\text { dry, apply silane with a brush } \\
\text { and gently air dry }\end{array}$ \\
\hline $\begin{array}{l}\text { Silane Coupling Agent; } \\
\text { Dentsply Ind. e Com. Ltda., } \\
\text { Petrópolis, RJ, Brazil }\end{array}$ & Silane & $\begin{array}{l}\text { Ethanol, } \\
\text { Acetic acid }\end{array}$ & 133203B & $\begin{array}{l}\text { Mix a drop of Silane Primer } \\
\text { and a drop of Silane Activator } \\
\text { for } 10 \text { to } 15 \mathrm{~s} \text {. Let stand for } \\
5 \mathrm{~min} \text {. Apply a thin layer on } \\
\text { the surface of post and air } \\
\text { dry. Apply a second coat and } \\
\text { air dry }\end{array}$ \\
\hline $\begin{array}{l}\text { Filtek }^{\mathrm{TM}} \text { Z250 Universal } \\
\text { Restorative; 3M ESPE, St. } \\
\text { Paul, MN, USA }\end{array}$ & $\begin{array}{l}\text { Inorganic filler (zirconium/silica) } \\
\text { loading is } 60 \% \text { by volume with a } \\
\text { particle size range of } 0.01 \text { to } 3.5 \\
\text { microns. BIS-GMA, UDMA and } \\
\text { BIS-EMA. }\end{array}$ & - & $8 \mathrm{HE}$ & $\begin{array}{l}\text { The resin is incrementally } \\
\text { placed in layer less than } 2.5 \\
\text { mm and each layer is cured } \\
\text { for } 20 \mathrm{~s} \text {. }\end{array}$ \\
\hline
\end{tabular}

*According to the manufacturers' instructions. 
radius; and $\mathrm{h}$, the thickness, and using the formula of a conical frustum (13):

$$
\text { Area } \left.=\pi\left(\mathrm{R}_{1}+\mathrm{R}_{2}\right) \sqrt{ } \mathrm{R}_{1}-\mathrm{R}_{2}\right)^{2}+\mathrm{h}^{2}
$$

A compressive push-out load was applied using a custom-built device that consisted of a $3 \mathrm{~cm}$ stainless steel base with a $2 \mathrm{~mm}$ center hole. The slice was centered over this hole before applying a compressive load at $0.5 \mathrm{~mm} / \mathrm{min}$ with a $1-\mathrm{mm}$-wide stainless steel rod in a universal testing machine (EMIC DL2000; EMIC, São José dos Pinhais, PR, Brazil) until failure. The force required to cause failure $(\mathrm{N})$ was recorded by a $200 \mathrm{~N}$ load cell hardwired to software (TESC; EMIC). The push-out bond strength was expressed in MPa by dividing the load $(\mathrm{N})$ at failure by the bonded area of the post segment $\left(\mathrm{mm}^{2}\right)(14,15)$.

The bond strength data were examined for normality of distribution (Kolmogorov-Smirnov test) and homogeneity in variances (Levene's test) and analyzed by two-way ANOVA to evaluate the effect of the study factors (silane and air drying temperature). Multiple comparisons were performed with Scott-Knott test $(\alpha=0.05)$. Dunnett's test compares the mean of each experimental group with that of control group.

Specimens tested were mounted on aluminum stubs, sputter coated with gold (Bal-Tec SCD 050; Balzers, Liechtenstein) and examined under a scanning electron microscope (LEO 435 VP; Carl Zeiss, Germany). SEM images were obtained at different magnifications to illustrate the failure modes.

\section{RESULTS}

Push-out bond strength mean values and standard deviations for the 8 experimental groups are presented in Table 2. For the air drying at room temperature $\left(23^{\circ} \mathrm{C}\right)$, the use of RelyX Ceramic Primer resulted in significantly lower bond strength $(p<0.05)$ than the other silane coupling agents. Warm air drying at $60^{\circ} \mathrm{C}$ for Silane Coupling Agent decreased significantly $(\mathrm{p}<0.05)$ the bond strength when compared to that produced by room temperature air drying. No significant difference $(p>0.05)$ was found between the temperatures for other silane agents tested in this study. Dunnett's test showed that the Silane Coupling Agent associated with air drying at room temperature $\left(23^{\circ} \mathrm{C}\right)$ resulted in significantly higher bond strength $(\mathrm{p}<0.05)$ than that of the control group. All the other experimental groups presented statistical similarity to control group (Table 3 ).

SEM and optical observations showed that mixed failure involving partial adhesive failure between post and composite resin core was the exclusive mode of failure in all specimens (Figs. 2 and 3). Figure 2 shows post extrusion in relation to composite build-up, representing a partial adhesive failure. Figure 3 shows that the post surface was partially covered with core material after testing.

\section{DISCUSSION}

The use of warm air drying after fiber post silanization did not improve the bond strength to composite resin core. The warm air drying at $60^{\circ} \mathrm{C}$ applied to Silane Coupling Agent decreased significantly the bond strength when compared to that produced by a room temperature air drying. Thus, the tested hypothesis was rejected.

Fiber post systems are usually selected for rehabilitation of endodontically treated teeth in order to retain the coronal portion, and not to reinforce the tooth-restoration complex (16). The combination of fiber post with an adhesive restoration is capable of creating homogenous stress distribution and decreasing catastrophic root fracture, with the possibility of replacing the restoration. However, resin core or post fractures are the failures that affect this type clinical procedure (4), justifying the evaluation of factors related to bond between FRC post and composite resin core

Different uppercase letters in rows and lowercase letters in columns indicate statistically significant difference at $\mathrm{p}<0.05$. 
located at coronal portion of teeth.

The push-out test is a method that has been considered more dependable on the microtensile test for testing interfacial bond strength for bonded posts $(14,16,17)$. The push-out test involves the use of an indenter to push a small diameter fiber into a composite specimen with a thickness of several millimeters. In this case, the test specimen is sufficiently thin (approximately $1 \mathrm{~mm}$ ) to enable the entire length of fiber to slide out of the matrix. Therefore, an additional advantage of using the "thin slice" push-out test is that multiple slices may be retrieved from a single bonded fiber post/composite core sample (1).

In a previous study, the push-out test showed a more homogenous stress distribution by finite element analysis and less variability in mechanical testing when compared with microtensile bond test (15). This experimental method presents features of testing conditions that must be considered, such as tensile stresses produced by the bending moment at load application (18). Therefore, this study used devices that are compatible with the diameter of the FRC post, where the load applicator had a diameter of $1.2 \mathrm{~mm}$, the push-out device had a role with $2.0 \mathrm{~mm}$ in diameter, and the post had a diameter of 1.5. Then the stress is concentrated at the interface homogeneously, which is a characteristic essential for a bonding test.

Silanes can be presented as single-phase preactivated solutions (prehydrolyzed) or two-component

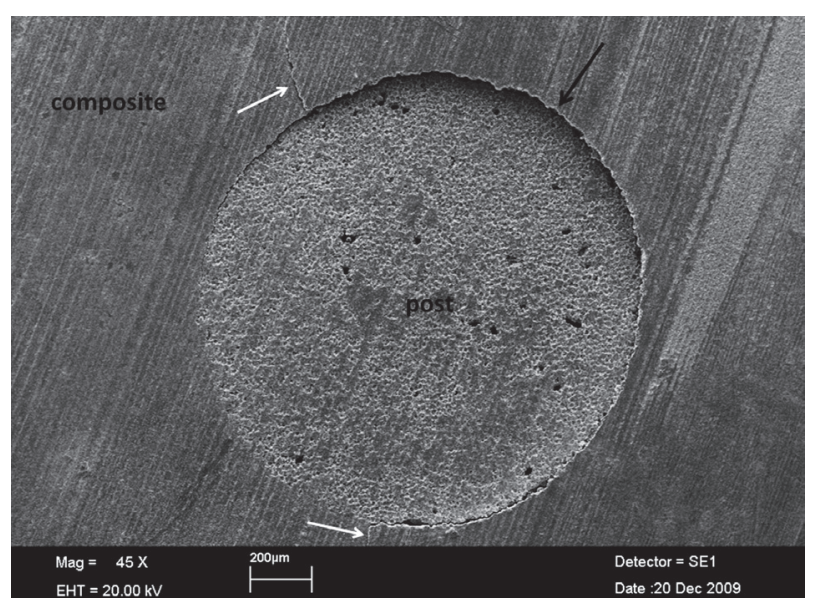

Figure 2. Illustrative SEM micrograph of the slice after testing. The black arrow in the figure shows the fiber-reinforced post being extruded of the composite build-up that represents partial adhesive failure. White arrows show the cohesive failure of the composite resin core (Original magnification $\times 45$ ). systems that must be mixed just before application in order to initiate the hydrolysis reaction (19). Silanes have the ability to bond inorganic materials such as glass, mineral fillers, metals, and metallic oxides to organic resins. The adhesion mechanism is due to two groups in the silane structure. The $\mathrm{Si}(\mathrm{OR})_{3}$ portion reacts with

Table 3. Means and standard deviation (SD) of push-out bond strength values (MPa) comparing the negative control group with the others by the Dunnett's test.

\begin{tabular}{lc}
\hline Group & Mean (SD) \\
\hline G1, negative group & $18.12(0.82) \mathrm{b}$ \\
G2, Silano Angelus $\left(23^{\circ} \mathrm{C}\right)$ & $20.29(2.32) \mathrm{b}$ \\
G3, Silano Angelus $\left(60^{\circ} \mathrm{C}\right)$ & $19.70(2.88) \mathrm{b}$ \\
G4, Prosil $\left(23^{\circ} \mathrm{C}\right)$ & $20.70(2.33) \mathrm{b}$ \\
G5, Prosil $\left(60^{\circ} \mathrm{C}\right)$ & $19.37(1.04) \mathrm{b}$ \\
G6, Relyx Ceramic Primer $\left(23^{\circ} \mathrm{C}\right)$ & $18.52(2.84) \mathrm{b}$ \\
G7, Relyx Ceramic Primer $\left(60^{\circ} \mathrm{C}\right)$ & $19.91(2.27) \mathrm{b}$ \\
G8, Silane Coupling Agent Dentsply $\left(23^{\circ} \mathrm{C}\right)$ & $21.66(2.49) \mathrm{a}$ \\
G9, Silane Coupling Agent Dentsply $\left(60^{\circ} \mathrm{C}\right)$ & $19.44(1.32) \mathrm{b}$ \\
\hline
\end{tabular}

Different letters indicate statistically significant differences.

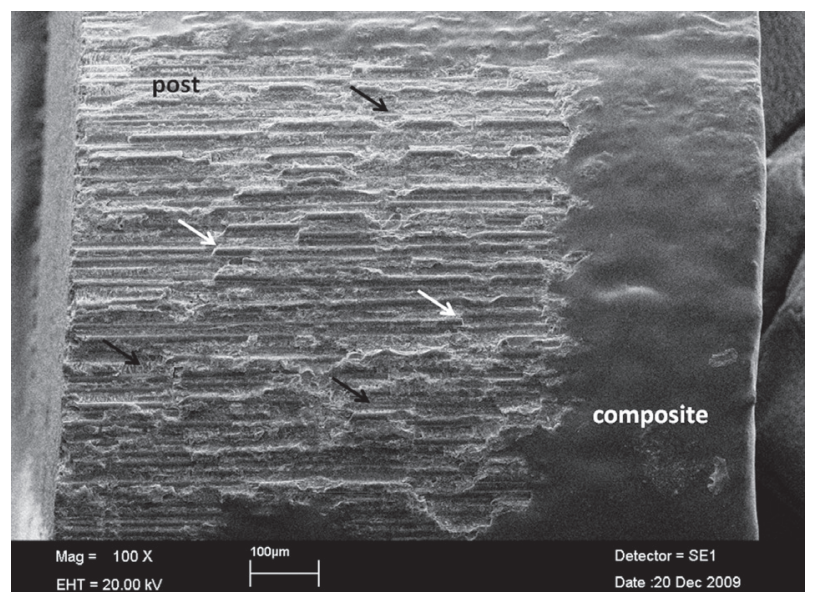

Figure 3. SEM micrograph of a post surface after fracture, illustrating the mixed nature of the failure mode. Composite resin remnants are partially evident. The black arrow indicates the epoxy resin exposed on the most of post surface. White arrows indicate the amount of the glass fiber exposed (Original magnification $\times 100$ ). 
the inorganic reinforcement, while the organofunctional (vinyl-, amino-, epoxy-, methoxy-) group reacts with the resin. When used as a coupling agent, the silane is defined as chemical substances capable of reacting with both the reinforcement and the resin matrix of a composite material. It may also bond inorganic fillers or fibers to organic resins, which promotes a stronger interface bonding. Then, the agent acts as interface between the resin and glass fiber to form a chemical bridge between the resin and fiber (20).

The present study showed that RelyX Ceramic Primer presented significantly lower bond strength values when air drying at room temperature was applied. On the other hand, when warm air drying at $60^{\circ} \mathrm{C}$ was used to evaporate the solvents, the bond strength values was similar to the other groups. The solvents of this material are ethyl alcohol and water, which is more difficult to be evaporated, and it probably increased the bond strength (11). Higher temperatures of warm air stream may facilitate water removal and increase bond strength (8).

The two-component Silane Coupling Agent has been proven to be more sensitive to heating. Ethanol, the solvent that is present in the two-bottle silane systems evaluated in this study, evaporates easily. Therefore, a rise in air drying temperature may improve solvent evaporation, but its extent is probably related to the volatile nature of the specific solvent. It probably explains the results achieved in this group, in which the values decreased after application of heating.

The bond strengths of the control group, in which no treatment was performed, presented no significant difference to the other groups, except for Silane Coupling Agent with air drying at $23^{\circ} \mathrm{C}$. These results are supported by those of other studies, which that showed no chemical bond between the composite resin core materials and the FRC posts, indicating no benefit from the preliminary application of silane coupling agents (3). Bond strength between the composite buildup and the FRC posts consists mainly of a combination of micromechanical interlocking and sliding friction. This can be seen in Figure 3 in which, after debonding, post surface is partially covered with core material. However, it is important to consider that although there was no statistically significant difference among almost all groups compared with the control group, the numerical values of all groups were higher than those of the control group.

Current FRC posts are composed of unidirectional fibers embedded in a resin matrix in which reinforcing quartz or glass fibers are immersed (17). The glass fiber posts used in this study are claimed by the manufacturer to contain $87 \%$ glass fiber and $13 \%$ epoxy resin, which is highly cross-linked and less reactive. Therefore, this post system has little functional groups to react with the silane solution (17). Additionally, there is no chemical union between the methacrylate-based resin composites and the epoxy resin matrix of fiber posts. This result seems to justify the similarity of values obtained between the control group and other groups in which silanes were used.

Since MPS silane does not bond well to the epoxy matrix, it might be possible that the silane effect of enhancing the post-core bond strength is increased when FRC posts with more superficial parts of fibers are used (3). When the post surface is conditioned with different protocols, a more reactive surface is generated because the superficial layer of epoxy resin is removed; this creates chemical and micromechanical retention. More epoxy resin matrix can be exposed on both glass and quartz fiber post surfaces with the application of hydrogen peroxide $(7,12)$. Thus, conditioning of the surface of FRC posts followed by silanization may enhance bond strengths to composite build-up $(7,12)$. Although the silane coupling agents are capable of forming bonds with both inorganic and organic structures, their application without surface pretreatment seems to be insufficient to improve the bond strength (20).

It may be concluded that the use of warm air drying after silane application produced no increase in the bond strength between FRC post and composite core. Additionally, warm air drying after use of the two-component Silane Coupling Agent resulted in significantly lower bond strength. The two-component Silane Coupling Agent produced higher bond strength than all pre-hydrolyzed silanes when its use was followed by air drying at room temperature $23^{\circ} \mathrm{C}$.

\section{RESUMO}

Este estudo avaliou o efeito da temperatura do ar e diferentes silanos na resistência de união entre pino de fibra e resina composta. Os pinos foram limpos com álcool e tratados com diferentes silanos: três pré-hidrolizados [Silano (Angelus), Prosil (FGM), RelyX Ceramic Primer (3M ESPE)] e um de dois componentes [Silane Coupling Agent (Dentsply)]. Duas temperaturas $\left(23^{\circ} \mathrm{C}\right.$ e $\left.60^{\circ} \mathrm{C}\right)$ para secagem do silano foram aplicadas. Matriz plástica cilíndrica foi posicionada em torno do pino já silanizado, e preenchida com resina composta simulando núcleo de preenchimento. Cada 
cilindro obtido pela união pino/preenchimento foi seccionado, gerando 7 fatias para ensaio mecânico de push-out. Aplicou-se sobre cada fatia carregamento de compressão, com velocidade de $0,5 \mathrm{~mm} / \mathrm{min}$, até a falha da amostra. Os dados foram analisados pela ANOVA e teste Scott-Knott $(\alpha=0,05)$. Utilizou-se teste de Dunnett para comparação do grupo controle com cada um dos outros grupos experimentais. Após ensaio mecânico, observaramse as amostras em microscópio eletrônico de varredura. Para $23^{\circ} \mathrm{C}$, RelyX Ceramic Primer apresentou os menores valores de resistência de união, enquanto o Silane Coupling Agent (Dentsply) obteve os maiores valores. Para o Silane Coupling Agent (Dentsply), os valores de resistência de união foram maiores para temperatura de $23^{\circ} \mathrm{C}$ do que $60^{\circ} \mathrm{C}$. Em conclusão, o uso de ar quente após aplicação do silano não gerou aumento nos valores de resistência de união entre pino de fibra e material de preenchimento de resina composta. O silano de dois componentes apresentou maior resistência de união do que todos os silanos pré-hidrolizados quando usados na temperatura ambiente.

\section{ACKNOWLEDGEMENTS}

\author{
The authors are indebted to financial support granted \\ by FAPEMIG and CNPq.
}

\section{REFERENCES}

1. Sadek FT, Monticelli F, Goracci C, Tay FR, Cardoso PE, Ferrari $\mathrm{M}$. Bond strength performance of different resin composites used as core materials around fiber posts. Dent Mater 2007;23:95-99.

2. Valandro LF, Ozcan M, de Melo RM, Galhano GA, Baldissara P, Scotti R, et al.. Effect of silica coating on flexural strength of fiber posts. Int J Prosthodont 2006;19:74-76.

3. Wrbas KT, Schirrmeister JF, Altenburger MJ, Agrafioti A, Hellwig E. Bond strength between fibre posts and composite resin cores: effect of post surface silanization. Int Endod J 2007;40:538-543.

4. Santos-Filho PC, Castro CG, Silva GR, Campos RE, Soares CJ. Effects of post system and length on the strain and fracture resistance of root filled bovine teeth. Int Endod J 2008;41:493-501.

5. Gateau P, Sabek M, Dailey B. Fatigue testing and microscopic evaluation of post and core restorations under artificial crowns. J Prosthet Dent 1999;82:341-347.

6. Goracci C, Raffaelli O, Monticelli F, Balleri B, Bertelli E, Ferrari $\mathrm{M}$. The adhesion between prefabricated FRC posts and composite resin cores: microtensile bond strength with and without postsilanization. Dent Mater 2005;21:437-444.
7. Monticelli F, Ferrari M, Toledano M. Cement system and surface treatment selection for fiber post luting. Med Oral Patol Oral Cir Bucal 2008;13:214-221.

8. Monticelli F, Toledano M, Osorio R, Ferrari M. Effect of temperature on the silane coupling agents when bonding core resin to quartz fiber posts. Dent Mater 2006;22:1024-1028.

9. de la Fuente JL, Madruga EL. A kinetic study of free-radical copolymerization of butyl acrylate with methyl methacrylate in solution. Macrom Chem Phys 1996;197:3743-3755.

10. Shen C, Oh W, Williams JR. Effect of post-silanization drying on the bond strength of composite to ceramic. J Prosthet Dent 2004;91:453-458.

11. Barghi N, Berry T, Chung K. Effects of timing and heat treatment of silanated porcelain on the bond strength. J Oral Rehabil 2000;27:407-412.

12. Akgungor G, Sen D, Aydin M. Influence of different surface treatments on the short-term bond strength and durability between a zirconia post and a composite resin core material. J Prosthet Dent 2008;99:388-399.

13. Bitter K, Priehn K, Martus P, Kielbassa AM. In vitro evaluation of push-out bond strengths of various luting agents to tooth-colored posts. J Prosthet Dent 2006;95:302-310.

14. Goracci C, Tavares AU, Fabianelli A, Monticelli F, Raffaelli O, Cardoso PC, et al.. The adhesion between fiber posts and root canal walls: comparison between microtensile and push-out bond strength measurements. Eur J Oral Sci 2004;112:353-361.

15. Soares CJ, Santana FR, Castro CG, Santos-Filho PC, Soares PV, Qian F, et al.. Finite element analysis and bond strength of a glass post to intraradicular dentin: comparison between microtensile and push-out tests. Dent Mater 2008;24:1405-1411.

16. Soares CJ, Soares PV, de Freitas Santos-Filho PC, Castro CG, Magalhaes D, Versluis A. The influence of cavity design and glass fiber posts on biomechanical behavior of endodontically treated premolars. J Endod 2008;34:1015-1019.

17. Perdigão J, Gomes G, Lee IK. The effect of silane on the bond strengths of fiber posts. Dent Mater 2006;22:752-758.

18. Armstrong S, Geraldeli S, Maia R, Raposo LHA, Soares CJ, Yamagawa J. Adhesion to tooth structure: A critical review of "micro" bond strength test methods. Dent Mater 2010;26:50-62.

19. Bitter K, Noetzel J, Neumann K, Kielbassa AM. Effect of silanization on bond strengths of fiber posts to various resin cements. Quintessence Int 2007;38:121-128.

20. Goyal S. Silanes: chemistry and applications. J Ind Prosthodont Soc 2006;6:14-18.

Received February 3, 2011 Accepted July 15, 2011 